\title{
Osmotic Extraction of Hypotonic Fluid from the Lungs
}

\author{
RichaRd M. EFFros \\ From the Department of Medicine, New Jersey School of Medicine, \\ Newark, New Jersey 07103
}

\begin{abstract}
A B S T RACT After injections of sucrose, $\mathrm{NaCl}$, and urea solutions, the flow of tissue fluid from the lungs amounted to $0.182,0.216$, and $0.152 \times 10^{-3} \mathrm{ml} / \mathrm{s}$ per mosmol $/ \mathrm{kg}$ of concentration difference between plasma and tissues in each gram of wet tissue weight. The extracted fluid contained less than $20 \%$ of the $\mathrm{Na}^{+}, \mathrm{K}^{+}$and urea concentrations of the plasma. It was concluded that this fluid was distinctly hypotonic in comparison with the fluids of the plasma and tissue compartments both before and after the injection of hypertonic solutions.

The presence of low solute concentrations in the extracted fluid is attributed to the passage of this fluid across cellular membranes, which are relatively impermeable to small hydrophilic solutes. Movement of fluid out of the junctions appears to be less than that through the endothelial cells. It is suggested that the injected solutes rapidly leak into the junctions and consequently induce relatively little movement of water or tissue solutes out of the junctions. Concentrations of tritiated water and $\left[{ }^{14} \mathrm{C}\right]$ antipyrine in the extracted fluid are essentially the same as base-line plasma concentrations when the animals have been primed with these tracers. It is therefore likely that these tracers can readily traverse cellular membranes.

Red cell transit through the lungs is impaired by hypertonic solutions of sucrose and $\mathrm{NaCl}$ with transient increases in pulmonary arterial hemoglobin concentrations of as much as $35 \%$ of base-line values.
\end{abstract}

\section{INTRODUCTION}

Basic to the Starling hypothesis of capillary fluid exchange is the assumption that the capillaries restrict the passage of large "proteid" molecules but readily permit the movement of water and small solute molecules, such as sodium and chloride ions (1-3). Starling found that

An abstract of this work was presented at the annual meeting of the Microcirculatory Society in 1973 and was published in Microvasc. Res. 6: 120-121, 1973.

Received for publication 3 July 1973 and in revised form 28 May 1974. the decline of intravascular pressure that followed acute hemorrhage resulted in the passage of isotonic fluid from the tissues to the blood. He concluded that the protein oncotic pressure of the plasma was responsible for this flow of isotonic fluid.

Over the past $20 \mathrm{yr}$, a number of studies have been made of the flow of fluid from tissues induced by hypertonic solutions of small solute molecules (4-8). The effect of leakage of small solute molecules out of the vascular space may be evaluated in terms of the reflection coefficients of the capillaries to these solutes (9). The reflection coefficients provide a measure of the relative efficacy of such solutions in dehydrating tissues in comparison to equivalent solutions of impermeant large molecules or decreases in capillary hydrostatic pressure. These reflection coefficients may be used to estimate the dimensions of the "pores" through which the small solute molecules leak $(5-7,10,11)$.

Although some information has been obtained on the quantity of fluid extracted from tissues by hypertonic solutions of low molecular weight solutes, there appears to be little information available on the nature of this fluid. In the present study, concentrations of hemoglobin, T-1824-labeled plasma protein, and a number of small solutes are measured in the blood emerging from the lungs after injections of hypertonic solutions. From these data, it is possible to determine not only the net quantity of fluid removed from the lungs, but the solute concentration of this fluid as well. In marked contrast to the isotonic tissue fluid flows observed by Starling after decreases in capillary hydrostatic pressure, the fluid removed from the lungs by hypertonic solutions of small solutes appears to be distinctly hypotonic. It is shown on the basis of a model of parallel flows through capillary cells and junctions that these observations are quite consistent with the Starling hypothesis that small solute molecules rapidly traverse the capillary walls.

\section{METHODS}

Two groups of experiments were performed. In the first group, measurements were made of the flow of fluid from 

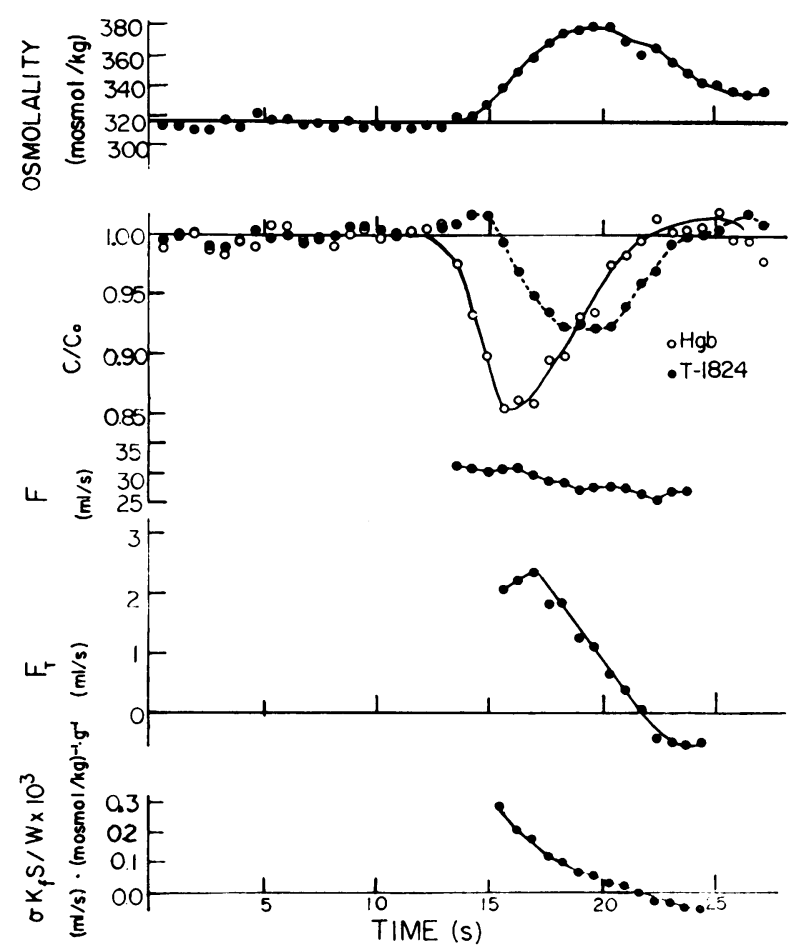

Figure 1 Response of tissue fluid flow to a bolus injection of sucrose. Upper panel: plasma osmolality (determined by freezing point depression). Second panel: Fractional changes in whole blood concentration of hemoglobin ( $\mathrm{Hgb})$ and T-1824. Note earlier and more pronounced decline of hemoglobin levels, attributed to impairment of red cell passage through the lungs. Third panel: "Instantaneous" pulmonary blood flow (based on $F_{\text {тно }}$ ). Fourth panel: calculated tissue fluid flow $\left(F_{T}\right)$. Negative values of $F_{T}$ indicate return of fluid to the tissue. Fifth panel: calculated values of $\sigma K_{f} S / W$ are plotted against time.

the lungs into the blood after rapid injections of hypertonic solutions of sucrose, $\mathrm{NaCl}$, or urea. An additional calculation was made of hemoglobin retention within the organ, observed after injections of hypertonic sucrose and sodium chloride.

In the second group of experiments, solute concentrations of the fluid removed from the lung after these injections were determined.

Osmolalities were measured by freezing-point determination of plasma samples. Methods for determining solute concentrations and activities are described in a previous publication (12).

Except where stated, all determinations were made in whole blood, and changes in concentration do not reflect movement of water or solutes between red cells and plasma of the collected blood.

Tissue fluid flow. Determination of tissue fluid flow was dependent upon measurement of the flow of blood through the lungs and the concomitant dilution of the blood by the fluid removed from the lung tissue.

Mongrel dogs were anesthetized with sodium pentobarbital (30 mg/kg, i.v., and $50 \mathrm{mg}$ as needed), intubated, and ventilated with a Harvard pump (Harvard Apparatus Co.,
Inc., Millis, Mass.) for the duration of the study. Intravenous injections of succinylcholine (20 $\mathrm{mg}$ and as needed), heparin (20,000-40,000 USP units), and T-1824 (300-500 $\mathrm{mg}$ in $30-50 \mathrm{ml}$ of $0.154 \mathrm{M} \mathrm{NaCl}, 30-60 \mathrm{~min}$ before the hypertonic injections were begun) were then administered. $\mathrm{T}-1824$ was used as a convenient indicator of plasma protein concentration (primarily albumin) (13).

The thorax was opened at the level of the left atrium and a double-lumen catheter was placed in the left atrium. A second catheter was placed in the superior vena cava by way of the right jugular vein and a third catheter was introduced into the aorta through the left carotid artery. Additional catheters were placed in the femoral artery (for blood pressure measurements) and the femoral vein (for intravenous saline infusion and i.v. medications).

A volume of $3.5-8 \mathrm{ml}$ of $2.25 \mathrm{M}$ sucrose, $2 \mathrm{M} \mathrm{NaCl}$, or 2-9.5 M urea was rapidly injected within a 2-s interval through the superior vena cava catheter. Blood was withdrawn at $4-6 \mathrm{ml} / \mathrm{s}$ from the aorta catheter with a peristaltic pump and collected in serial tubes, which were changed at $\frac{1}{3}-\frac{3}{4}-\mathrm{s}$ intervals by a moving rack collector.

Measurement of the pulmonary blood flow that prevailed as the hypertonic bolus and the fluid extracted from the lungs arrived in the aorta was determined in the following manner: A solution of tritiated water $(\mathrm{THO})^{1}$ in isotonic saline $(10 \mathrm{mCi} /$ liter $)$ was infused at a constant rate $(0.14$ $\mathrm{ml} / \mathrm{s}$ ) by a syringe pump into one lumen of the left atrial catheter. This infusion was begun $5 \mathrm{~s}$ before the hypertonic bolus was injected into the superior vena cava. Concentrations of the tritiated water were determined in blood collected from the aorta and blood flow $\left(F_{\text {тно }}\right)$ leaving the lungs was calculated from the dilution of the tritiated water:

$$
F \text { тно }=\frac{\left[\mathrm{THO}_{i}\right.}{[\mathrm{THO}]_{b}} I
$$

where $[\mathrm{THO}]_{\imath}$ and $\left[\mathrm{THO}_{b}\right.$ designate the THO activity of the infusion solution and collected blood samples and $I$ represents the flow rate of the infusion solution. (The contribution of the infusion rate to the blood flow was negligible and was therefore neglected.)

The success of this procedure depends upon documentation that influx and efflux of the tritiated water through the left heart and proximal aorta are equal when flow is measured. This was accomplished by giving a bolus of [ $\left.{ }^{225} \mathrm{I}\right]$ albumin through the second lumen of the left atrial catheter when the THO infusion began. It was assumed that when the $\left[{ }^{125} \mathrm{I}\right]$ albumin bolus had fully emerged in the aortic blood, influx and efflux of the THO through the left heart and aorta had become equal. It was found in five studies that the outflow patterns of THO and $\left.{ }^{125} \mathrm{I}\right]$ albumin were the same and that the recirculation of $\left[{ }^{125} \mathrm{I}\right]$ albumin (judged from a rise in concentrations above exponentially extrapolated values) could be used to predict recirculation of THO. These studies indicated that when blood flow was measured with the THO infusion in the experiments reported in this paper, the outflow of THO averaged 0.97

${ }^{1}$ Abbreviations frequently used in this paper: $F$, blood flow; $F_{T}$, true tissue fluid flow; $F_{T, u}$, uncorrected tissue fluid flow; $H$, maximum excess pulmonary retention of hemoglobin; Hgb, hemoglobin; $I$, flow rate of infusion; $K_{f}$, filtration constant; $S$, capillary surface area; $\sigma$, Staverman reflection coefficient; THO, tritiated water; $\tau$, collection tube interval; $W$, wet weight of tissue; $w$, fractional concentration. (Additional symbols are defined in the text.) 
$\pm 0.03^{2}(n=18)$ of the infusion rate of THO and recirculation of THO to the outflow site produced an average error of only $0.03 \pm 0.03 \quad(n=18)$ in the calculated blood flow. Good correlations were found between flows determined by the THO infusions and flows calculated in the same experiments from the areas under the indicator dilution curves of $\left[{ }^{125} \mathrm{I}\right]$ albumin, osmolality, and the injected solute concentrations. ${ }^{3}$

It was assumed that the contribution to outflow made by the red cells present in the outflow at any time could be estimated from the measured hemoglobin concentration of the collected sample and the ratio between the hematocrit and hemoglobin concentration of the control blood. Similarly, it was assumed that the contribution to outflow made by plasma that had traversed the organ could be estimated from the T-1824 concentration of the collected samples and the ratio between the plasmacrit $(1-\mathrm{Hct})$ and the $\mathrm{T}-1824$ concentration of the control blood. There are three additional sources from which fluid outflow from the lung might be derived: $(a)$ the injection volume, $(b)$ the pulmonary tissues, and (c) red cells transiently trapped within the organ after injections of sucrose or sodium chloride (an effect described below). Flow of fluid from all three of these sources is designated as $F_{T, u}$ and is calculated from the equation:

$$
\begin{aligned}
F_{r, u}=\{1-[\mathrm{Hgl}) & \frac{\mathrm{Hct}_{o}}{[\mathrm{Hgb}]_{0}} \\
& \left.-[\mathrm{T}-1824] \frac{1-\mathrm{Hct}_{o}}{[\mathrm{~T}-1824]_{o}}\right\} F_{\text {THO }}
\end{aligned}
$$

where $F_{r, u}$ refers to the calculated tissue fluid flow (uncorrected for the injection artifact described below); [ $\mathrm{Hgb}$ ] and $[\mathrm{Hgb}]$ refer to the hemoglobin concentration in blood perfusing the organ before the hypertonic injection and in the collected sample after the injection; [T-1824]。 and [T1824] similarly refer to base-line and collection sample con-

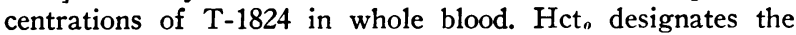
base-line hematocrit, and $F_{\text {TH }}$ designates the cardiac output determined from the THO dilution in the collected sample.

The injection bolus contained neither red cells nor $T$ 1824-labeled albumin and the whole blood concentrations of hemoglobin and T-1824 in the collection samples were therefore diluted by the injection fluid ("injection artifact"). Dilution of the collected blood by the injection solution proved to be modest, and an approximate correction for this artifact was accomplished by assuming that the arrival of the injection fluid in the collected blood coincided with the arrival of the injected solute and could be estimated from the osmolality curve. Subtraction of the fluid flow attributed to the injection volume from the uncorrected tissue fluid flow $\left(F_{T, u}\right)$ yielded the true tissue fluid flows $\left(F_{T}\right)$, indicated in Figs. 1, 2, and 3.

After injections of hypertonic sucrose or sodium chloride, the flow of red cells through the organ is impaired relative to the concomitant flow of plasma. This effect has been

All means are provided with standard deviations.

${ }^{3} F_{\text {1nd }}=1.23 F_{\text {THO }}-5.84, r=0.79, n=15, P<0.001 . F_{\text {osm }}$ $=1.19 F_{\mathrm{THO}}-5.08, r=0.82, n=20, P<0.001 . F_{125_{\mathrm{I}}}=0.80$ $F_{\text {THO }}+4.59, r=0.84, n=18, P<0.001 . F_{\text {ind, }}, F_{\text {osm }}$, and $F$ refer to the pulmonary blood flow calculated from the areas under the injected solute, osmolality, and [ $\left.{ }^{125} \mathrm{I}\right]$ albumin curves and $F_{\text {тно designates flow calculated for the observa- }}$ tion interval from the THO infusion.
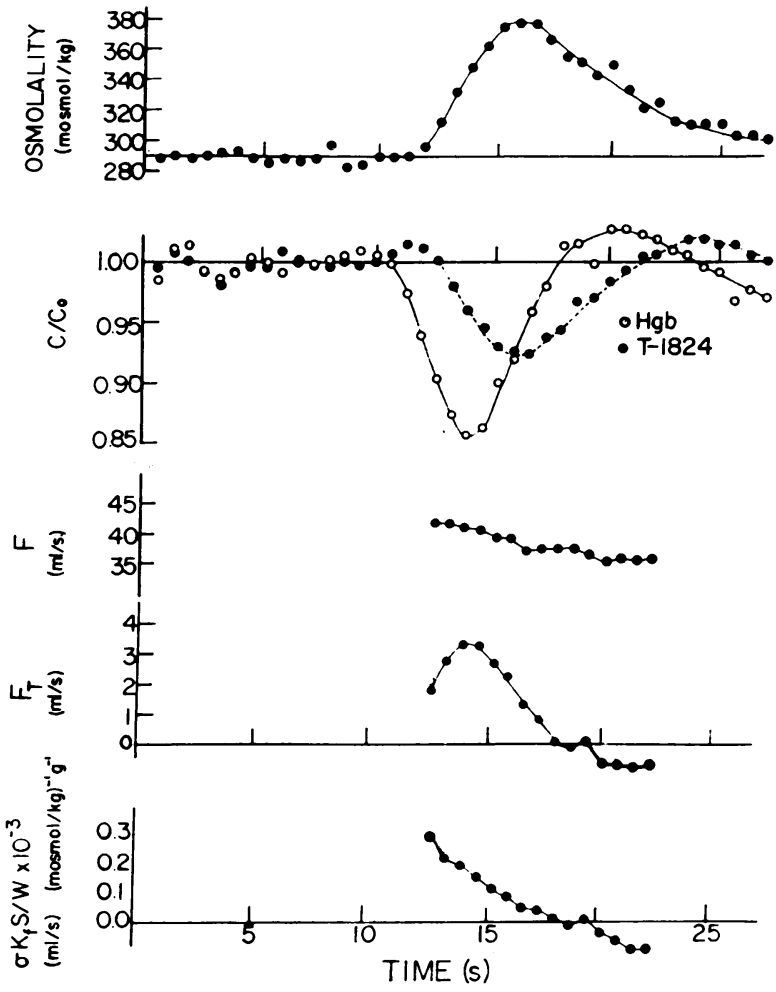

Figcre 2 Response of tissue fluid flow to a bolus injection of $\mathrm{NaCl}$ (see legend of Fig. 1).

described in detail elsewhere and the transient retention of hemoglobin within the lung is quantitated below. It is not possible from the present data to be sure what portion of the outflow $\left(F_{r}\right)$ is derived from "trapped" red cells rather than by tissue in these experiments. However, as indicated in the Results section, there appeared to be no correlation between the prevailing hematocrit and the relative rate at which fluid was withdrawn from the organ, suggesting that the contribution from retained red cells was modest.

Measurements of the flow of fluid from the lung were confined to the early samples containing both the injected solution and tissue fluid. I assumed that maximal tissue fluid flows will occur upon the initial exposure of the capillary bed to the hypertonic solution, before tissue solute concentrations have increased appreciably. I also assumed that the tissue fluid present in these early samples was derived from a relatively small portion of the lung: specifically, that portion with relatively short transit times. I further assumed that the solute present in these early samples traversed the same small portion of the lung and the observed fluid flows were compared with the observed increases in osmolality to characterize the response of these portions of the lung to the rise in osmolality. In effect, it was assumed that the tissue fluid and the injected solute leaving the capillaries are diluted to the same extent by blood from areas of the lung not yet exposed to the injected solute. The permeability of this portion of the lung may not be representative of the permeability of the lung as a whole.

Evidence will be presented that the fluid extracted from the lungs contains very low concentrations of solute. Entry 

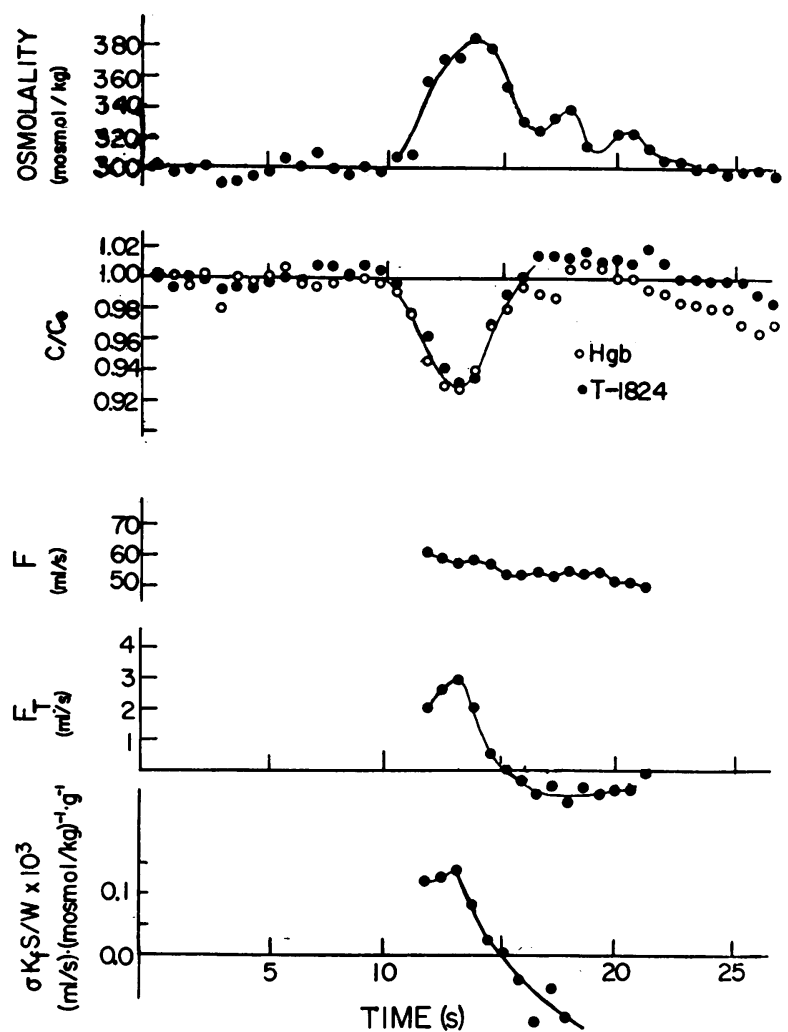

Figure 3 Response of tissue fluid flow to a bolus injection of urea. Upper panel: see legend of Fig. 1. Second panel: Note proportional decline of hemoglobin and T-1824 concentrations. No evidence of selective impairment of red cell flow was demonstrated. Third, fourth, and fifth panels : see legend of Fig. 1.

of this dilute tissue fluid into the vascular space should decrease the osmolality of the blood perfusing the lungs. I have assumed that the pulmonary arterial osmolality $\left(\mathrm{C}_{\mathbf{2}}\right)$ and pulmonary venous osmolality $\left(C_{v}\right)$ of the blood perfusing the lungs are related by the equation

$$
\mathrm{C}_{\mathrm{a}}=\mathrm{C}_{\mathrm{v}} F \mathrm{THO} /\left(F \mathrm{THO}-F_{T}\right)
$$

where $F_{\mathrm{T}}$ represents the flow of tissue fluid and $F_{\text {тно }}$ designates the outflow from the lung determined with THO infusion. Like Bohr (14), Kety (15), Renkin (16), Crone (17), and Yudilevich, Renkin, Alvarez, and Bravo (18) and subsequent workers, I assumed that the osmolality of the blood containing injected solute declines exponentially from the arterial to the venous ends of the exchange area of the lung. Thus the average osmolality along the capillary may be calculated from the measured venous osmolality and the derived arterial osmolality with the equation:

$$
\bar{C}=\frac{C_{a}-C_{v}}{\ln C_{a}-\ln C_{v}}
$$

Furthermore, it has been assumed that tissue concentrations remain unchanged at early times and the observed flow of tissue water has been produced by an osmotic gradient across the capillary wall equal to $\bar{C}-C_{0}$, where $C_{0}$ represents the osmolality of the blood and tissues before the osmotic bolus was injected.

Provided hydrostatic pressure gradients are relatively small compared to the imposed osmotic gradients, then

$$
F_{T}=\sigma K_{f} S\left[\overline{\mathrm{C}}-\mathrm{C}_{o}\right]
$$

where $\sigma$ is the Staverman reflection coefficient (9) and provides a measure of the relative flow of fluid through the capillary wall induced by the osmotic pressure gradient in comparison to an equivalent hydrostatic pressure gradient. $K_{f}$ is the filtration constant in units of $\mathrm{ml} \mathrm{s}^{-1}$ (mosmol/ $\mathrm{kg}$ $\left.\mathrm{H}_{2} \mathrm{O}\right)^{-1} \mathrm{~cm}^{-2}$, and $S$ represents the capillary surface area $\left(\mathrm{cm}^{2}\right)$. In the present experiment, values have been obtained for $F_{T} /\left[\left(\mathrm{C}-\mathrm{C}_{0}\right) W\right]$ where $W$ represents the wet weight of the lung. This quantity is designated by the equivalent term $\sigma K_{1} S / W$ at the bottom of Figs. 1, 2, and 3 .

Excess hemoglobin retention. After injections of hypertonic sucrose or sodium chloride solutions, the decline in hemoglobin concentration of blood leaving the organ exceeded the concomitant decline in whole blood T-1824 concentrations. This is illustrated in Figs. 1 and 2. This observation was reported in an earlier publication (12) in which tracer studies also indicated that red cell transit through the lungs was impaired by injections of these solutions. It was not possible, however, to calculate the quantity of hemoglobin retained by the organ in excess of $\mathrm{T}$ 1824-labeled albumin in these earlier studies because measurements of pulmonary blood flow during the collection of each sample of blood were not obtained. In the present studies, these measurements of flow were made with the THO infusion technique and it was therefore possible to calculate the quantity of hemoglobin retained within the lung in excess of proportional quantities of T-1824-labeled albumin.

The maximum retention of hemoglobin (up to the time when T-1824 concentrations in the effluent blood became proportionately greater than corresponding hemoglobin concentrations) was calculated from the equation:

$$
H=\sum_{a}^{b}\left\{\frac{[\mathrm{T}-1824]_{i}[\mathrm{Hgb}]_{0}}{[\mathrm{~T}-1824]_{0}}-[\mathrm{Hgb}]_{i}\right\} F \tau
$$

where $H$ represents the maximum quantity (in grams) of hemoglobin stored within the organ over and above the corresponding quantity of albumin within the organ, $a$ represents the time when $[\mathrm{Hgb}]_{1} /[\mathrm{Hgb}]_{\text {。 began to decline and }}$ $b$ the time when $[\mathrm{Hgb}]_{1} /[\mathrm{Hgb}]_{0}$ again became equal to $[\mathrm{T}-1824]_{\imath} /[\mathrm{T}-1824]_{0}$. [Hgb]。/[T-1824]。 designates the ratio between the hemoglobin and T-1824 found in the collected sample, and $\tau$ represents the collection tube interval.

Tissue fluid solute concentrations. A second set of studies was performed to obtain information on the solute concentration of fluid extracted from lungs. In these studies no attempt was made to measure instantaneous blood flow, and flow was determined from the areas under the osmotic concentration curves. The left atrial catheters were not inserted and the tritiated water infusion and [ $\left.{ }^{130} \mathrm{I}\right]$ albumin injections were not given. The experimental procedure was otherwise unchanged: The hypertonic solution was injected into the superior vena cava and aortic blood was pumped into the collection tubes. In addition to hemoglobin and $\mathrm{T}-1824$, whole blood concentrations of sodium and potassium were determined by flame photometry. 
Values were calculated for the concentrations of $\mathrm{Na}^{+}$and $\mathrm{K}^{+}$in the extracted tissue fluid by solving the equations:

$$
\begin{gathered}
{\left[\mathrm{Na}^{+}\right]_{B, i}=[\mathrm{Hgb}]_{B, i} \frac{\left[\mathrm{Na}^{+}\right]_{R, o}}{[\mathrm{Hgb}]_{R, o}}} \\
+[\mathrm{T}-1824]_{B, i} \frac{\left[\mathrm{Na}^{+}\right]_{P, o}}{[\mathrm{~T}-1824]_{P, o}}+\left[\mathrm{Na}^{+}\right]_{T, i} \frac{F_{T, u}}{F} \\
{\left[\mathrm{~K}^{+}\right]_{B, i}=[\mathrm{Hgb}]_{B, i} \frac{\left[\mathrm{K}^{+}\right]_{R, o}}{[\mathrm{Hgb}]_{R, o}}} \\
+[\mathrm{T}-1824]_{B, i} \frac{\left[\mathrm{K}^{+}\right]_{P, o}}{[\mathrm{~T}-1824]_{P}}+\left[\mathrm{K}^{+}\right]_{T, i} \frac{F_{T, u}}{F}
\end{gathered}
$$

where the subscripts $B, P$, and $R$ refer to whole blood, plasma, and red cells and $o$ and $i$ refer, respectively, to the control sample obtained before the injection and the $i^{\text {th }}$ sample collected after the injection. $\left[\mathrm{Na}^{+}\right]_{r, 4}$ and $\left[\mathrm{K}^{+}\right]_{r, 4}$ designate extracted tissue fluid concentrations of $\mathrm{Na}^{+}$and $\mathrm{K}^{+}$. Values for $F_{r, w} / F$ were obtained from Eq. 2 .

No distinction was made between fluid extracted from the lungs and that removed from trapped red cells. As indicated above, impairment of red cell movement through the lungs was observed after injections of sucrose and $\mathrm{NaCl}$. In some of these studies, correction for the injection artifact was made but proved to be insignificantly different from uncorrected values, and the latter values are tabulated (Table II). If it is assumed that $\mathrm{Na}^{+}$and $\mathrm{K}^{+}$concentrations in the tissue fluid are zero, then the concentrations of $\mathrm{Na}^{+}$and $\mathrm{K}^{+}$ in the outflow blood can be predicted with Eqs. 7 and 8 by making the last term of each equation zero. These "predicted" values are compared with "observed" values in the bottom of Figs. 4 through 6 . Correspondence of the predicted and observed curves was dependent upon how close to zero tissue fluid concentrations of these solutes actually



FIgURE 4 Relative absence of sodium and potassium ions in fluid extracted from the lungs by an injection of a hypertonic sucrose solution. Whole blood concentrations of $\mathrm{Na}^{+}$ and $\mathrm{K}^{+}$were predicted from concomitant hemoglobin and $\mathrm{T}-1824$ concentrations (upper panel) by assuming that the extracted fluid did not contain either ion. Predicted concentrations are compared with observed concentrations in the lower two panels.
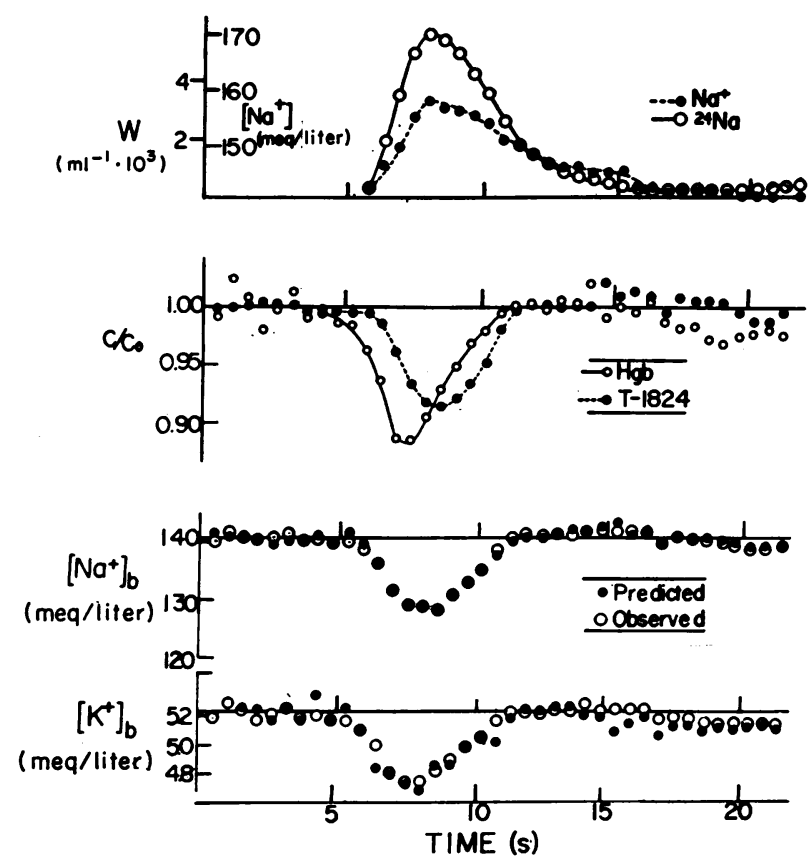

FIGURE 5 Relative absence of sodium and potassium ions in fluid extracted from the lungs by an injection of hypertonic sodium chloride solution. The injection solution was labeled with ${ }^{2} \mathrm{Na}$ to permit distinction of injected and resident sodium concentrations. Whole blood concentrations of $\mathrm{Na}^{+}$and the fractional concentrations (w) of ${ }^{2 \mathrm{Na}}$ are shown in the upper panel. Whole blood concentrations of resident $\mathrm{Na}^{+}$and $\mathrm{K}^{+}$(third panel) were predicted from concomitant hemoglobin and T-1824 concentrations (second panel) by assuming that the extracted fluid did not contain either ion. Predicted concentrations are compared with "observed" concentrations of $\mathrm{Na}^{+}$corrected for $\mathrm{Na}^{+}$introduced with the injection bolus in the lower two panels.

were in these experiments. ${ }^{24} \mathrm{Na}$ was incorporated with the hypertonic $\mathrm{NaCl}$ injection solutions to permit distinction between that part of the observed $\mathrm{Na}^{+}$concentrations derived from the injection solution and that part already within the animal. ${ }^{24} \mathrm{Na}$ activities were divided by the total activity of injected " $\mathrm{Na}$ (yielding $\mathrm{w}$, "fractional concentrations" in $\mathrm{ml}^{-1}$ ) and these values are compared with changes in total $\mathrm{Na}^{+}$concentration in the upper panel of Fig. 5 . "Observed" $\mathrm{Na}^{+}$concentrations indicated in the third panel of this figure represent total concentrations corrected for the injected $\mathrm{NaCl}$.

Additional experiments were performed to evaluate the movement of $\left[{ }^{14} \mathrm{C}\right]$ urea, tritiated water, and $\left[{ }^{14} \mathrm{C}\right]$ antipyrine (labeled at the $n$-methyl site) out of pulmonary tissue after injections of hypertonic sucrose, sodium chloride, and urea. In these studies a priming dose of the labeled material was given $30-120 \mathrm{~min}$ before the injection of the hypertonic solution. It was assumed that after this interval of time, concentrations of the tracers would be equal in the vascular and extravascular compartments. The equivalent concentrations of these tracers in the fluid extracted from the lungs were determined from equations analogous to Eq. 7 and 8 .

The coefficients of variation for spectrophotometric determinations of hemoglobin and T-1824 concentrations 


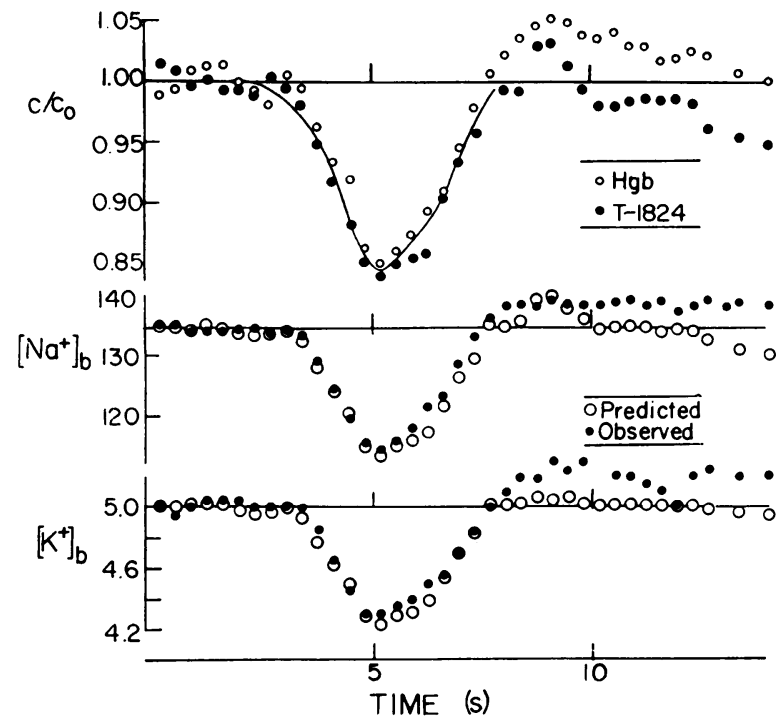

FIgUre 6 Relative absence of sodium and potassium ions in fluid extracted from the lungs by an injection of a hypertonic urea solution. See legend of Fig. 4.

amounted to $0.5 \%$, whereas values of approximately $1.0 \%$ were obtained for osmolality and sodium and potassium concentrations. If tissue fluid flow is $10 \%$ of the cardiac output, then errors of $1 \%$ in absolute concentrations of any of these determinations will produce errors of $10 \%$ in calculated values of $\sigma K_{f} S / W$ or estimated concentrations of sodium or potassium in the extracted fluid. The presence of random errors of this nature is reflected in the standard deviations of the reported data (Tables I and II). Similar variation (dependent upon the activity of the samples) was found for the radioactive determination.

\section{RESULTS}

Site of fluid cxtraction. In view of the considerably greater surface area of the pulmonary capillaries (over $10 \mathrm{~m}^{2}$ in a 200-g lung) (19) in comparison to the surface area of the great vessels and the walls of the cardiac chambers (less than $0.2 \mathrm{~m}^{2}$ ), it is likely that most of the water extracted by hypertonic solutions is derived from the lungs rather than the heart or large vessels.

The observation that the mean transit times of THO and $\left[{ }^{125} \mathrm{I}\right]$ albumin injected into the left atrium are essentially the same indicates that the rapidly exchangeable water volume in the left heart and base of the aorta is negligible. In addition, collection of blood from the pulmonary artery after hypertonic injections of sucrose and $\mathrm{NaCl}$ in two studies (not shown) failed to detect the extraction of water from the superior vena cava or the walls of the right atrial or ventricular cavities during the normal interval of the study (25 s). It is therefore concluded that the extracted tissue fluid was primarily obtained from the exchange area of the lungs.
Tissue fluid flow and homoglobin retention. The initial flow of tissue fluid into the blood stream after injections of hypertonic solutions of sucrose, $\mathrm{NaCl}$, and urea is reflected by fractional declines in hemoglobin and T-1824. These data are indicated with plasma osmolality in Figs. 1, 2, and 3, in which concentrations are expressed as fractions of average base line values $\left(\mathrm{C} / \mathrm{C}\right.$ o refers to $[\mathrm{Hgb}] /[\mathrm{Hgb}]_{\circ}$ and $[\mathrm{T}-1824] /[\mathrm{T}$ 1824]。).

This period of tissue dehydration was followed by a return of fluid to the tissue in the blood, which followed the hypertonic bolus. During this latter process, hemoglobin and $\mathrm{T}-1824$ concentrations rose above base line levels.

After injections of hypertonic sucrose and $\mathrm{NaCl}$, hemoglobin concentrations fell more rapidly than $\mathrm{T}-1824$ concentrations and later increased above the corresponding T-1824 concentrations (Figs 1 and 2). This observation has been described more fully in a previous publication (12) and has been ascribed to a loss of red cell deformability with a consequent temporary retention of red cells in excess of comparable amounts of $\mathrm{T}-1824$ entering the lungs. The maximum excess pulmonary retention of hemoglobin $(H)$ over and above $\mathrm{T}$-1824 retained within the lungs has been calculated by Eq. 15 and these values are presented in Table I. $H$ averaged $2.25 \pm 1.70 \mathrm{~g}(\mathrm{SD}, n=7)$ after $\mathrm{NaCl}$ injections and $1.63 \pm 1.21 \mathrm{~g}(\mathrm{SD}, n=7)$ after sucrose injections. The equivalent declines in hemoglobin and T-1824 concentrations observed with injections of urea (Fig. 3) is consistent with the observation that urea rapidly enters red cells and therefore does not produce persistent red cell dehydration, diminished deformability or impairment of red cell passage through the lungs.

The pulmonary outflow $(F)$ for the interval during which tissue water was extracted was calculated from the THO infusion data (Eq. 1) and has been plotted in the same figures. During this brief interval, blood flow generally remained relatively constant : the mean fractional variation during the four-sample observation interval (see below) averaged $0.035 \pm 0.02 \quad(n=20)$.

The flow of extracted fluid was calculated from the blood flow data, and the hemoglobin and T-1824 data with Eq. 2, and is presented in Figs. 1, 2, and 3 below the blood flow data. These flows were corrected for the injection artifact (see Methods) and only the corrected values $\left(F_{T}\right)$ are indicated. Tissue fluid flows rose to an average fraction of $0.087 \pm 0.046(n=20)$ of the total pulmonary blood flow in these studies but rapidly declined and flow ceased within $5-10 \mathrm{~s}$ after it had begun; at a time when plasma osmolality averaged $61 \%$ of the maximum osmolality attained. At the end of the four-sample observation interval, the net total loss of fluid from the 
TABLE I

Pulmonary Blood Flow, Solute Reflection Coefficients, and Hemoglobin Retention Determined from Solute Injection Experiments

\begin{tabular}{|c|c|c|c|c|c|c|c|c|c|}
\hline Experiment & $\begin{array}{c}\text { Dog } \\
\text { weight }\end{array}$ & $\begin{array}{l}\text { Lung } \\
\text { weight }\end{array}$ & Hcto $_{0}$ & $\mathrm{Hgb}_{0}$ & $\begin{array}{l}\text { Amount } \\
\text { injected }\end{array}$ & $\begin{array}{l}\text { Maximum } \\
\text { increase in } \\
\text { osmolality }\end{array}$ & $F_{\text {Tно }}$ & $\sigma \frac{K_{f} S}{W}$ & $H$ \\
\hline & $\mathrm{kg}$ & $g$ & & $\mathrm{~g} / 100 \mathrm{ml}$ & mol & mosmol/kg & $m l / s$ & $\begin{array}{c}(\mathrm{ml} / \mathrm{s}) 10^{-3} \\
(\mathrm{mosmol} / \mathrm{kg}) \mathrm{g}\end{array}$ & $g$ \\
\hline \multicolumn{10}{|l|}{ Sucrose } \\
\hline $1-1$ & 17.3 & 236 & 0.38 & 9.9 & 10.8 & 51 & 50.9 & 0.237 & 1.38 \\
\hline $2-2$ & 19.2 & 269 & 0.41 & 15.3 & 10.7 & 47 & 38.8 & 0.083 & 0.47 \\
\hline $3-1$ & 18.6 & 215 & 0.46 & 15.1 & 17.3 & 96 & 26.0 & 0.293 & 3.35 \\
\hline $4-2$ & 17.0 & 187 & 0.34 & 12.3 & 15.3 & 89 & 36.5 & 0.192 & 0.71 \\
\hline $5-3$ & 19.8 & 290 & 0.51 & 17.8 & 14.0 & 85 & 30.2 & 0.079 & 2.72 \\
\hline $6-3$ & 21.5 & 180 & 0.47 & 13.1 & 16.3 & 106 & 21.0 & 0.229 & 2.46 \\
\hline $7-2 *$ & 30.0 & 344 & 0.16 & 6.2 & 15.3 & 65 & 50.7 & 0.164 & 0.31 \\
\hline Mean & & & & & & & & 0.182 & 1.63 \\
\hline SD & & & & & & & & 0.080 & 1.21 \\
\hline \multicolumn{10}{|l|}{$\mathrm{NaCl}$} \\
\hline $1-2$ & 17.3 & 236 & 0.42 & 9.6 & 12.7 & 46 & 33.1 & 0.258 & 1.17 \\
\hline $2-1$ & 19.2 & 269 & 0.40 & 15.8 & 12.6 & 45 & 45.1 & 0.129 & 1.16 \\
\hline $3-3$ & 18.6 & 215 & 0.44 & 15.7 & 15.5 & 173 & 26.7 & 0.298 & 5.57 \\
\hline $4-2$ & 17.0 & 187 & 0.34 & 12.1 & 13.7 & 107 & 50.3 & 0.201 & 1.88 \\
\hline $5-2$ & 19.8 & 290 & 0.52 & 17.5 & 12.5 & 85 & 41.4 & 0.251 & 2.26 \\
\hline $6-1$ & 21.5 & 180 & 0.48 & 13.6 & 14.6 & 122 & 29.5 & 0.226 & 3.18 \\
\hline $7-1^{*}$ & 30.0 & 344 & 0.15 & 6.7 & 13.6 & 30 & 60.4 & 0.149 & 0.50 \\
\hline Mean & & & & & & & & 0.216 & 2.25 \\
\hline SD & & & & & & & & 0.061 & 1.70 \\
\hline \multicolumn{10}{|l|}{ Urea } \\
\hline $1-2$ & 17.3 & 236 & 0.42 & 10.1 & 10.8 & 4.3 & 23.3 & 0.184 & \\
\hline $2-3$ & 19.2 & 269 & 0.40 & 15.7 & 10.7 & 41 & 26.8 & 0.061 & \\
\hline $3-1$ & 18.6 & 215 & 0.46 & 16.1 & 26.6 & 122 & 36.1 & 0.190 & \\
\hline $4-3$ & 17.0 & 187 & 0.35 & 10.9 & 23.6 & 106 & 43.4 & 0.229 & \\
\hline $5-1$ & 19.8 & 290 & 0.53 & 17.6 & 21.5 & 65 & 59.0 & 0.139 & \\
\hline $6-2$ & 21.5 & 180 & 0.46 & 13.4 & 25.2 & 132 & 29.0 & 0.113 & \\
\hline Mean & & & & & & & & 0.152 & \\
\hline SD & & & & & & & & 0.060 & \\
\hline
\end{tabular}

Abbreviations: F THO, pulmonary blood flow determined from tritiated water infusion data; Hcto, hematocrit before injection; Hgb, hemoglobin concentration before injection; $\sigma K f S / W$ data were calculated as indicated in text from Eq. $5 ; H$, maximum excess hemoglobin stored within the organ (Eq. 6).

* Animal bled and infused with saline to diminish hematocrit.

lung averaged $2.8 \%, 3.7 \%$, and $2.9 \%$ of the pulmonary water content, estimated from the wet weight of the lungs.

As indicated in the Methods section, knowledge of the tissue fluid flow $\left(F_{T}\right)$, the change in serum osmolality $(\Delta \mathrm{C})$, and the wet weight of the lung $(W)$ permitted calculation of the term $\sigma K_{f} S / W$. Values for $\sigma K, S / W$ were calculated from data obtained in the early sample tubes and are plotted in the bottom panels of Figs. 1, 2, and 3. These values decline rapidly and only the first four points were averaged to obtain estimates of $\sigma K_{f} S / W$ when tissue fluid flows are maximal. $\sigma K_{f} S / W$ for sucrose, $\mathrm{NaCl}$, and urea averaged $0.182 \pm$ $0.080(n=7), 0.216 \pm 0.061 \quad(n=7)$, and $0.152 \pm 0.052$ $(n=6) \mathrm{ml} \mathrm{s}^{-1}(\operatorname{mosmol} / \mathrm{kg})^{-1}$ (g wet tissue wt) $)^{-1}$. No significant differences were found between these values, nor were correlations found between $\sigma K_{f} S / W$ values for any of the solutes and the flow per unit weight of tissue, the maximum venous osmolality, or the base-line hemoglobin concentration or hematocrit.

Solute concentrations in the extracted fluid. If it is assumed that the water that leaves the lungs in response to the osmotic bolus contains no $\mathrm{Na}^{+}, \mathrm{K}^{+}$, or $\left[{ }^{14} \mathrm{C}\right]$ urea (after an earlier priming dose of $\left[{ }^{14} \mathrm{C}\right]$ urea), then the concentrations of these small solutes in the blood leaving the organ can be predicted from the concomitant hemoglobin and T-1824 concentrations with Eqs. 7 and 8 and an analogous equation for $\left[{ }^{14} \mathrm{C}\right]$ urea. The relative success of this procedure is illustrated in Figs. 4, 5, and 6 for $\mathrm{Na}^{+}$and $\mathrm{K}^{+}$, in which the predicted concentrations of $\mathrm{Na}^{+}$and $\mathrm{K}^{+}$are compared with the observed data. In those experiments in which $\mathrm{NaCl}$ was injected (Fig. 5), it was necessary to distinguish between the injected $\mathrm{Na}^{+}$and "resident" $\mathrm{Na}^{+}$already present within the blood and/or tissues at the time of injection. This was accomplished by labeling the injected $\mathrm{Na}^{+}$with ${ }^{2} \mathrm{Na}^{+}$and 
TABLE II

Calculated Solute Concentrations in Extracted Fluid

\begin{tabular}{clccc}
\hline & & \multicolumn{3}{c}{ Fraction of plasma concentration } \\
\cline { 3 - 5 } $\begin{array}{c}\text { Extracted } \\
\text { solute }\end{array}$ & $\begin{array}{l}\text { Injection } \\
\text { solution }\end{array}$ & Mean & SD & $n$ \\
\hline $\mathrm{Na}^{+}$ & Sucrose & 0.03 & 0.14 & 8 \\
& NaCl & 0.16 & 0.23 & 13 \\
& Urea & 0.00 & 0.09 & 7 \\
$\mathrm{~K}^{+}$ & & 0.03 & 0.18 & 8 \\
& Sucrose & 0.00 & 0.27 & 16 \\
& NaCl & 0.01 & 0.13 & 5 \\
[14C]Urea & Urea & 0.12 & 0.18 & 4 \\
& Sucrose & 0.19 & 0.12 & 5 \\
& NaCl & 0.10 & 0.22 & 4 \\
THO & Urea & 0.96 & 0.07 & 3 \\
& Sucrose & 0.97 & 0.05 & 3 \\
& NaCl & 1.02 & 0.10 & 8 \\
\hline
\end{tabular}

calculating resident $\mathrm{Na}^{+}$with Eqs. 7 and 8 from the total and labeled $\mathrm{Na}^{+}$concentrations. The values of total $\mathrm{Na}^{+}$and labeled $\mathrm{Na}^{+}$are indicated in the upper portion of Fig. 5.

The actual solute concentrations in the initial flow of tissue fluid from the lungs have been calculated with Eqs. 7 and 8 from the differences found between the observed and predicted solute concentrations. These values have been divided by prevailing concentrations of solute in the plasma and are presented in Table II. As indicated under Methods, these values are not corrected for the injection artifact, since corrected and uncorrected mean values were not significantly different in those experiments in which enough data was collected. Furthermore, some of the extracted with sucrose and $\mathrm{NaCl}$ solutions is presumably derived from trapped red cells. The presence of negative values for some of the calculated solute concentrations in the extracted fluid represents an apparent entry of solute into the tissues of the lung when fluid is being removed from the lungs.

It is evident from Figs. 4, 5, and 6 and the data presented in Table II that water extracted from the lungs is accompanied by relatively small quantities of small solute molecules. Average concentrations of $\mathrm{Na}^{+}, \mathrm{K}^{+}$, and urea in extracted fluid were less than $20 \%$ of base-line plasma values after injections of $\mathrm{NaCl}$, sucrose, and urea. The standard deviations are relatively great and no significant differences were found between these values.

As anticipated, the osmotic flow of water out of the tissue does carry with it tritiated water (administered as a priming dose before the experiment). The failure of THO concentrations to decline significantly after an injection of urea is indicated in Fig. 7. Calculated concentrations of THO in the extracted fluid remained close to base-line plasma concentrations (Table II). Concentrations of $\left[{ }^{\mathrm{IA}} \mathrm{C}\right]$ antipyrine also failed to decline after injections of hypertonic urea in each of two experiments (not shown).

\section{DISCUSSION}

Tissue fluid flow. Losses of fluid from the lung tissue after sudden injections of hypertonic solutions observed in the present study are considerably more rapid than would be anticipated from data published by Taylor and Gaar (7). These investigators estimated pulmonary capillary reflection coefficients $(\sigma)$ from the ratio of $F_{\boldsymbol{r}}$, tissue fluid flow from the lungs induced by hypertonic infusions, to the flow $\left(F_{P}\right)$ of fluid into the same quantity of tissue produced by corresponding increases in capillary hydrostatic pressures:

$$
\sigma=\frac{\left[F_{T} /(\Delta \mathrm{C} W)\right]}{\left[F_{P} R T /(\Delta P W)\right]}
$$

where $\Delta \mathrm{C}$ is the osmotic concentration difference between the infusion fluid and the tissues before infusion, $\Delta P$ represents the increase in capillary hydrostatic pressure, $R$ is the gas constant, and $T$ is the absolute temperature. Taylor and Gaar reported that the reflection coefficients of urea, glucose and sucrose were $0.018 \pm 0.003,0.026 \pm 0.002$, and $0.044 \pm 0.004(\mathrm{SEM})$, respectively. The corresponding values for $F_{T} /(\Delta \mathrm{CW})$ are not provided by these authors but may be estimated from their own estimates of the pulmonary capillary reflection coefficient $K_{f}\left(7.1 \times 10^{-11} \mathrm{~cm}^{3} /\right.$ dyne-s $)$ and $\mathrm{S}$ per gram of tissue $\left(480 \mathrm{~cm}^{2} / \mathrm{g}\right)$ :

$$
F_{T} /(\Delta \mathrm{C} W)=\sigma F_{P} R T /(\Delta P W)=\sigma K_{f} S / W
$$

Calculated values of $F_{\mathrm{r}} /(\Delta \mathrm{CW})$ for urea, glucose and sucrose derived from their study average $0.0158 \times 10^{-5}$, $0.0228 \times 10^{-3}$, and $0.0386 \times 10^{-3}(\mathrm{ml} / \mathrm{s})(\mathrm{mosmol} / \mathrm{kg})^{-1}$ $\mathrm{g}^{-1}$. In the present study $F_{T} /(\Delta \mathrm{CW})$ for urea, $\mathrm{NaCl}$, and sucrose averaged $0.152 \times 10^{-8}, 0.216 \times 10^{-8}$, and 0.182 $\times 10^{-8}(\mathrm{ml} / \mathrm{s})(\mathrm{mosmol} / \mathrm{kg})^{-1} \mathrm{~g}^{-1}$.

Injections of sodium chloride and sucrose in this study resulted in transient retention of red cells within the lungs. It is therefore likely that some of the fluid removed from the lungs with these solutions was derived from retained red cells rather than the lung itself. However, red cell retention does not occur after injections of urea. Furthermore, the rate of fluid removal after injections of sodium chloride and sucrose did not appear to be correlated with the prevailing hematocrit. It must therefore be concluded that significantly more fluid has been extracted from the lung in the present study than would be anticipated from the study of Taylor and Gaar.

The experimental procedure of Taylor and Gaar differed in five major respects from the procedure reported here. (a) Taylor and Gaar used a perfused excised lung preparation mounted on a balance, whereas 
the lungs were left in situ in this study. (b) Increases in vascular osmolality were imposed as sustained infusions in their experiments; plasma osmotic pressures were increased transiently in the present experiments. (c) Although sustained for longer intervals, increases in osmolality in the Taylor and Gaar report were smaller than those produced in the present study. Taylor and Gaar indicate osmolalities ranging from 20 to 36 mos$\mathrm{mol} / \mathrm{kg}$. In the present study venous osmolalities transiently increased by $41-173 \mathrm{mosmol} / \mathrm{kg}$ and even greater osmolalities must have been present at the capillary level. (d) Measurements of tissue fluid flow were based upon changes in lung weight in their studies, whereas losses of tissue fluid in the present study were based upon dilution of blood flowing from the lungs. $(e)$ Measurements were made relatively later in the Taylor and Gaar studies. Observations were made at 6 -s intervals by Taylor and Gaar whereas observations were made at 0.75 -s intervals in this study.

Perl, Chowdhury, and Chinard (8) in our laboratory have recently repeated the studies of Taylor and Gaar using a rapidly responding strain gauge to monitor early changes in organ weight after very small increases in perfusion osmolality (from 1.0 to $5.0 \mathrm{mosmol} / \mathrm{kg}$ ). They observed a rapid decline in the rate of tissue dehydration after approximately $5 \mathrm{~s}$, as would be predicted from the response of the lungs to injections of much more concentrated solutions found in the present in situ study. Using the initial rate of loss of organ weight for their calculations, these investigators calculated reflection coefficients very much greater than those obtained by Taylor and Gaar at later times: $\sigma_{\mathrm{NaC1}}=0.3, \sigma_{\mathrm{s} \text { lueose }}=$ $0.3, \sigma_{\text {sucrose }}=0.3$, and $\sigma_{\text {raftinose }}=0.2$. These values are of the same order of magnitude as those calculated for cat hindlimb $(4,11)$ and rabbit heart capillaries (5). Taylor and Gaar (7) have suggested that the pulmonary capillary reflection coefficients, which they reported, were too low, since they necessitated the presence of "pores" or junctions as large as $80 \AA$ in diameter, larger than those observed in morphological studies. Since tissue osmolality must approach vascular osmolality with the passage of time, it is likely that the osmotic gradients responsible for the flows observed by Taylor and Gaar after $5 \mathrm{~s}$ have declined significantly from initial values. The sustained slow flow observed by these investigators may represent the movement of water into the pulmonary capillaries from more remote areas, perhaps those areas normally perfused by the bronchial circulation. Because some degree of equilibration between the pulmonary tissues and even the earliest samples of collected blood must have occurred, the values for $\sigma K_{r} S / W$ reported in the present study, as well as the reflection coefficient values reported by Perl et al. (8), may underestimate the true values of $\sigma K_{r} S / W$.

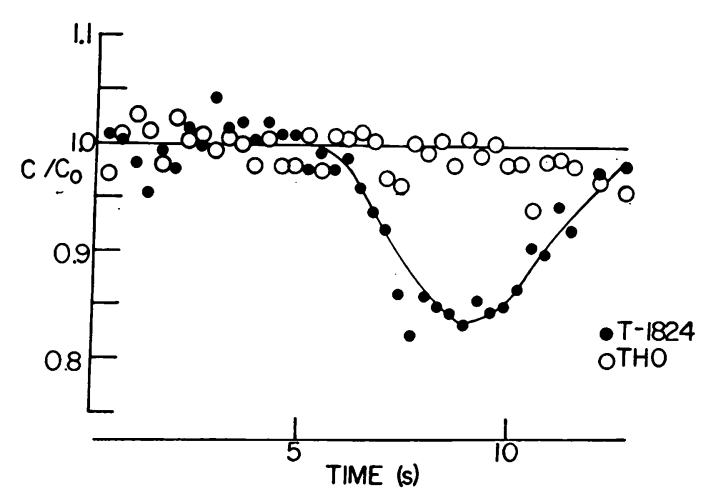

FIGURE 7 Presence of THO in fluid extracted from the lung by a bolus injection of a hypertonic urea solution. The activity of THO in the blood leaving the lung remained essentially unchanged despite the presence of tissue fluid in the collected blood (indicated by the decline in $\mathrm{T}-1824$ concentrations).

Solute concentration of extracted tissue fluid. It is apparent from the present studies that fluid extracted from the lungs with injections of hypertonic solutions of small solute molecules contains relatively low concentrations of $\mathrm{Na}^{+}, \mathrm{K}^{+}$, and urea. Since these solutes and corresponding anions constitute a very large portion of the extravascular solute content, it is reasonable to assume that the fluid removed from the lungs is hypotonic relative to the osmolality of the blood and tissues both before and after the injection. The relative failure of small hydrophilic solute molecules to accompany water leaving the tissues indicates the presence of barriers permeable to water but relatively impermeable to these solutes.

The movement of water between the blood and lung tissue may occur through the endothelial cells or the junctions between the endothelial cells. It has been variously estimated that from $15 \%$ (11) to $50 \%(20,21)$ of the flow of fluid into tissues after increases in capillary hydrostatic pressure traverses the endothelial cells. Because cell membranes are relatively impermeable to small lipophobic molecules, it has been suggested that the fluid which passes through the endothelial cells is very hypotonic (21). It is further assumed that these solute molecules are carried into the interstitium by water flowing through the interendothelial junctions. Although earlier reports suggested that pulmonary capillaries are relatively impermeable to small lipophobic solutes (22), more recent evidence suggests that these substances readily enter the pulmonary parenchyma, presumably by way of the intercellular junctions (23, 24). This hypothesis is illustrated in Fig. 8A. It should be noted that if the flow of hypotonic fluid into and across the capillary cell results in a local decline in solute concentration, flow by way of the cellular path

Osmotic Dehydration of the Lungs 
A

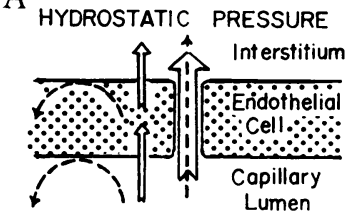

C

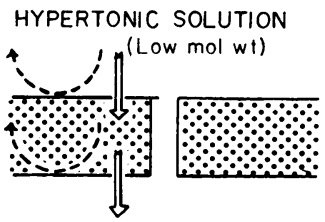

B HYPERTONIC SOLUTION (High mol wt)

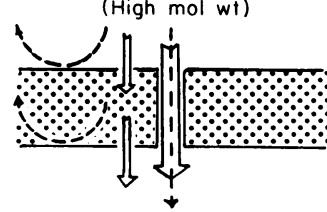

D ISOGRAVIMETRIC STUDY

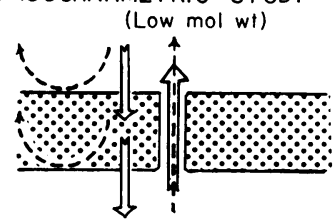

$\Longrightarrow$ FLOW OF WATER

$\rightarrow-\rightarrow$ RESIDENT SOLUTE FLUX

Figure 8 Parallel path model of fluid and resident solute movements through the pulmonary capillary cells and junctions in response to (A) a rise in capillary hydrostatic pressure; (B) an increase in the vascular concentration of a high molecular-weight substance; (C) an increase in the vascular concentration of a low molecular-weight substance; (D) and a simultaneous isogravimetric increase in serum osmolality (with a low molecular weight substance) and capillary hydrostatic pressure.

will decrease relative to the concomitant flow through the junctions (this effect is discussed in the Appendix). The accumulation of edema fluid may therefore largely proceed through the junctions rather than the endothelial cells.

If large molecules are injected and do not leak into the interstitium, then similar though opposite flows of water through cells and water, and solute through junctions, may be anticipated (Fig. 8B).

It is proposed that the injection of hypertonic solutions of small lipophobic solutes is followed by the rapid leakage of the injected solute through the junctions into the interstitium. In the limiting case, illustrated in Fig. 8C and presented in conventional irreversible thermodynamic terms in the Appendix, the injected solute is totally excluded from the endothelial cells but rapidly leaks through the junction and pulls no fluid out of the junction. This is equivalent to the assumptions that the reflection coefficient of the cell to the solute is one and the reflection coefficient of the junction is zero. Under these circumstances, one would expect that all of the extracted fluid would pass through the cellular path unaccompanied by solute. Furthermore the observed flow would represent the flow through the cells that would occur if the capillary hydrostatic pressure rather than the osmotic pressure were increased to the same extent.

Data obtained in these experiments suggest that most of the water extracted from the lungs by hypertonic solutions of small lipophilic molecules does pass through

the endothelial cells. Since the solute concentrations of the extracted fluid average less than $20 \%$ of plasma and presumably interstial solute concentrations, it would appear likely that the cellular path is responsible for more than $80 \%$ of the observed flow. These observations are consistent with the hypothesis that the reflection coefficients of the junctions are very low. On the assumption that the narrowest portion of the interendothelial junctions is only $40 \AA$ wide, Perl (11) has calculated that the reflection coefficients of the interendothelial junctions should be 0.035 for $\mathrm{NaCl}, 0.209$ for sucrose, and 0.052 for urea.

It is probable that arrival of the injection solution at the capillaries initially produces endothelial dehydration, rapidly followed by interstitial and then epithelial cell dehydration. As interstitial solutes become more concentrated, some diffusion of these solutes into the plasma should occur by way of the junctions. However, it was difficult to demonstrate reproducible entry of solute into the vascular space in the present experiments. This may reflect the insensitivity of the technique to relatively slow solute fluxes out of the interstitial volume. On the other hand, it is possible that the interstitium never becomes very contracted. If the injected solute rapidly penetrates the junctions, then the osmolality of the interstitium will increase because of the entry of injected solute rather than the loss of water, and cellular rather than interstitial dehydration will occur. It may be expected that during a constant infusion of a hypertonic solution, equilibration of the infused solute between the vascular space and interstitium will eventually occur and at that time only cellular dehydration would be present.

Two additional factors may tend to diminish the movement of interstitial water and solute out of the lung. It has been suggested by Guyton, Granger, and Taylor (25) that the structural components of the interstitial compartment tend to keep the compartmental volume from diminishing with the creation of subatmospheric interstitial hydrostatic pressures. These relatively negative pressures would tend to inhibit the flow of fluid out of the interstitium. In addition, the movement of injected solute into the junction may produce a local flow into the interstitium when the majority of flow is proceeding in the opposite direction through the cells, an effect described in frog skin by Ussing and others (26-28). Thus although it is likely that significant cellular dehydration occurs after these injections, the shortterm effects of such solutions upon interstitial volume remain unclear. As indicated above, prolonged infusions of these solutions should result in the eventual return of the interstitium to its original volume. The ultimate volume of the interstitial compartment should be determined by standard Starling relationship between the 
hydrostatic pressures and macromolecular composition of the vascular and interstitial volumes.

Expansion of the interstitial compartment must inevitably occur in isogravimetric experiments. In these studies (4), the flow of fluid out of the tissue in response to a hypertonic infusion is prevented by raising the capillary hydrostatic pressure. Although changes in organ weight may be avoided in this fashion, consiclerable local fluid circulation may be anticipated if the solute can leak through the pores. This illustrated in Fig. 8D. Hypotonic fluid leaves the tissue in response to the hypertonic infusion. An equal and opposite flow of fluid containing solute traverses the junctions under the influence of the hydrostatic pressure gradient. The rise in tissue osmolality is therefore dependent upon loss of hypotonic fluid and leakage of the infused solutes into the tissues. The entry of solute into the tissue is produced both by diffusion and solvent drag through the junctions: because solvent drag in the isogravimetric preparation increases solute flux into the tissue, measurements of capillary permeability to solutes in such preparations should be somewhat higher than tracer measurements of permeability in the absence of convectional effects.

The observation that THO accompanies the flow of water out of the lung probably reflects movement of the tracer and bulk water through the same channels. Although concentrations of $\left[{ }^{14} \mathrm{C}\right]$ antipyrine in the extracted fluid are also much the same as $\left[{ }^{14} \mathrm{C}\right]$ antipyrine concentrations in the plasma and probably the tissue compartments as well, it should not be assumed that antipyrine traverses the capillary wall with bulk water. Since the solubility of antipyrine in lipid exceeds the solubility of water in lipid, it is possible that some of the antipyrine traverses lipid pathways that may differ from the pathways accessible to bulk water movement. Passage of the antipyrine from the tissue to blood may result from diffusion as local concentrations increase with loss of tissue water rather than from the convective force of solvent drag.

Pulmonary red cell retention. Impairment of red cell passage through the lungs after injections of hypertonic sucrose and sodium chloride was again observed (12). Because concomitant blood flow was determined as well as hemoglobin and T-1824-labeled plasma protein concentrations, it was possible in the present study to determine the quantity of hemoglobin in excess of corresponding quantities of plasma protein retained within the lung. This amounted to an average of $1.63 \mathrm{~g}$ after sucrose injections and $2.25 \mathrm{~g}$ after $\mathrm{NaCl}$ injections. If it is assumed that the arterial volume is $50 \mathrm{ml}$ (29) and pulmonary arterial hemoglobin concentration is $14 \mathrm{~g} / 100$ $\mathrm{ml}$, then a 25 or $35 \%$ rise in pulmonary arterial hemoglobin concentration may be anticipated after these in- jections. As indicated previously, impairment of red cell passage is attributable to a decline in red cell deformability due to red cell dehydration $(12,30,31)$. Urea rapidly enters red cells ( $t$ of equilibration, approximately $\frac{1}{3}$ s) (32) and hypertonic urea solutions do not appreciably decrease red cell deformability or impair red cell passage through the lungs.

\section{APPENDIX}

A parallel pathway model similar to a number of previous models $(11,21,33-35)$ has been used to predict the effect of injections of hypertonic solutions of small solute molecules. The following symbols are used: $A_{j}, A_{c}$, areas of junctions and cells $\left(\mathrm{cm}^{2}\right) ; \bar{c}_{r}$, resident solute concentration in tissue (mol/liter); $F_{j}, F_{c}$, the flows of fluid through junctions and cells $(\mathrm{ml} / \mathrm{s}) ; F_{T, O}, F_{T, P}$, the flow of fluid into the tissue in response to a rise in osmolality; in hydrostatic pressure $(\mathrm{ml} / \mathrm{s}) ; J_{r}$, flux of resident solute from tissue to blood $(\mathrm{mol} / \mathrm{s}) ; L_{P, j}, L_{P, c}$, filtration constants of junctions and cells $\left(\mathrm{ml} \mathrm{s}^{-1} \mathrm{~cm}^{-2}\right.$ torr $\left.{ }^{-1}\right) ; \Delta P$, hydrostatic pressure difference across capillary wall (torr); $\Delta \pi_{i}$, osmotic pressure difference across capillary wall produced by injected solute (torr); $\sigma_{c, i}, \sigma_{c, r}$, solute reflection coefficients of cells to injected and resident solutes; $\sigma_{j, i}$, $\sigma_{j, r}$, solute reflection coefficients of junctions to injected and resident solutes.

As a limiting case, assume that for a hypertonic solution of some specific injected solute $i$, the following conditions are met: $(a)$ the reflection coefficient of the junctions is zero; $(b)$ the reflection coefficient of the cells is one; (c) concentrations of all solutes other than the injected solute remain the same in the vascular and extravascular compartments; and $(d)$ there are no hydrostatic pressures gradients across the capillary wall.

Then the flow of water from tissue to blood may be calculated from the equation:

$$
\begin{aligned}
F_{T, o}=F_{j}+F_{c}= & \sigma_{j} A_{j} L_{P, j} \Delta \pi_{i} \\
& +\sigma_{c} A_{c} L_{P, c} \Delta \pi_{i}=A_{c} L_{P, c} \Delta \pi_{\imath} .
\end{aligned}
$$

Consider now the flow of water produced by an increase in capillary hydrostatic pressure in the absence of any increase in solute concentration:

$$
F_{T, P}=A_{j} L_{P, j} \Delta P+A_{c} L_{P, c} \Delta P .
$$

Comparison of Eq. $1 \mathrm{~A}$ and $2 \mathrm{~A}$ shows that the flow elicited by the injected solute equals the corresponding portion of the flow that traverses the cell path when hydrostatic pressure is increased by the same amount.

With respect to the movement of other solutes within the tissue, let us further assume that: $(a)$ the reflection coefficient of the cells to the resident solute is one; $(b)$ there is no interaction between the movement of resident and injected solute. Then the movement of resident solute out of the tissue should be zero because $F_{j}$ and $\left(1-\sigma_{c, r}\right)$ are each zero:

$$
J_{r}=\left(1-\sigma_{j, r}\right) \bar{c}_{r} F_{j}+\left(1-\sigma_{c, r}\right) \bar{c}_{r} F_{c}=0
$$

Although Eq. 2A may correctly predict the initial flow of fluid through cells and junctions after an increase in hydrostatic pressure, flow through cells will tend to decline 
as the osmolality of the tissues is diminished by hypotonic fluid traversing the cells. Since the reflection coefficient of the cells to small solute molecules within the tissue (such as $\mathrm{Na}^{+}$and $\mathrm{Cl}^{-}$) is presumably much greater than the corresponding reflection coefficient at the junctions, the decline in tissue osmolality relative to plasma osmolality will serve to diminish flow of water through the cells more than flow of solution through the junctions. Any distention of the capillaries with increased hydrostatic pressure may also serve to widen the junctions and increase the flow through the junctions $(36,37)$.

\section{ACKNOWLEDGMENTS}

The good advice and encouragement of Drs. William Perl and Francis P. Chinard throughout these studies is acknowledged. Miss Kathleen Marold was responsible for the arduous analytical procedures, which were performed very competently. Mrs. Barbara McDonald and Miss Anne Haberle provided expert secretarial assistance.

This work was supported in part by NHLI research grants HL12879 and HL15490 and NHLI career development award HL70649 and a grant from the Life Insurance Medical Research Fund.

\section{REFERENCES}

1. Starling, E. H. 1896. On the absorption of fluids from the connective tissue. J. Physiol. (Lond.). 19: 312-326.

2. Starling, E. H. 1896. The Arris and Gale lectures on the physiological factors involved in the causation of dropsy. Lecture I. The production of the lymph. Lancet. 1: 1267-1270.

3. Starling, E. H. 1908. The absorption of the interstitial fluids in the fluids of the body. Herter Lectures. 1909. Keener and Co., Chicago. 88-103.

4. Pappenheimer, J. R., E. M. Renkin, and L. M. Borrero. 1951. Filtration, diffusion and molecular sieving through peripheral capillary membranes. A contribution to the pore theory of capillary permeability. Am. J. Physiol. $167: 13-46$.

5. Vargas, F., and J. A. Johnson. 1964. An estimate of reflection coefficients for rabbit heart capillaries. J. Gen. Physiol. 47 : 667-677.

6. Fenstermacher, J. D., and J. A. Johnson. 1966. Filtration and reflection coefficients of the rabbit blood-brain barrier. Am. J. Physiol. 211: 341-346.

7. Taylor, A. E., and K. A. Gaar, Jr. 1970. Estimation of equivalent pore radii of pulmonary capillary and alveolar membranes. Am. J. Physiol. 218: 1133-1140.

8. Perl, W., P. Chowdhury, and F. P. Chinard. 1973. Osmotic reflection coefficient of dog lung endothelium to sodium chloride glucose, sucrose, raffinose and albumin. Microvasc. Res. 6: 125-126. (Abstr.)

9. Staverman, A. J. 1951. The theory of measurement of osmotic pressure. Rec. Trav. Chim. Pays- Bas. 70: 344352.

10. Solomon, A. K. 1968. Characterization of biological membranes by equivalent pores. J. Gen. Physiol. 51: 335s-364s.

11. Perl, W. 1971. Modified filtration-permeability model for transcapillary transport-a solution of the Pappenheimer pore puzzle? Microvasc. Res. 3: 233-251.
12. Effros, R. M. 1972. Impairment of red cell transit through the canine lungs following injections of hypertonic fluids. Circ. Res. $31: 590-601$.

13. Rawson, R. A. 1943. Binding of $T-1824$ and structurally related diazo dyes by the plasma proteins. $A m$. J. Physiol. 138 : 708-717.

14. Bohr, C. 1909. Uber die spezifische Tätigkeit der Lungen bei der respiratorischen Gasaufnahme und ihr Verhalten zu der durch die Alveolarwand stattfindendan Gasdiffusion. Skand. Arch. Physiol. 22: 221-280.

15. Kety, S. S. 1951. Theory and applications of the exchange of inert gas at the lungs and tissues. Pharmacol. Rev. 3: 1-41.

16. Renkin, E. M. 1959. Transport of potassium-42 from blood to tissue in isolated mammalian skeletal muscles. Am. J. Physiol. 197 : 1205-1210.

17. Crone, C. 1963 . The permeability of capillaries in various organs as determined by use of the "indicator diffusion" methods. Acta Physiol. Scand. 58: 292-305.

18. Yudilevich, D. L., E. M. Renkin, O. A. Alvarez, and I. Bravo. 1968. Fractional extraction and transcapillary exchange during continuous and instantaneous tracer administration. Circ. Res. 23 : 325-336.

19. B. Siegwart, P. Gehr, J. Gil, and E. R. Weibel. 1971. Morphometric estimation of pulmonary diffusion capacity. IV. The normal dog lung. Respir. Physiol. 13: 141-159.

20. Yudilevich, D. L., and O. A. Alvarez. 1967. Water, sodium and thiourea transcapillary diffusion in the dog heart. Am. J. Physiol. 213 : 308-314.

21. Tosteson, D. C. 1970. Discussion. In Capillary Permeability. C. Crone and N. A. Lassen, editors. Academic Press, Inc., New York. 658-664.

22. Chinard, F. P., and T. Enns. 1954. Transcapillary pulmonary exchange of water in the dog. Am. J. Physiol. 178: $197-202$.

23. Wangensteen, O. D., L. E. Wittmers, Jr., and J. A. Johnson. 1969. Permeability of the mammalian blood-gas barrier and its components. Am. J. Physiol. 216: 719727.

24. Chinard, F. P., W. Perl, and R. M. Effros. 1971. Theoretical and practical considerations on the measurement of extravascular lung water. In Central hemodynamics and gas exchange. C. Giuntini, editor. Minerva Medica (Edizioni), S. A., Torino, Italy. 57-75.

25. Guyton, A. C., H. J. Granger, and A. E. Taylor. 1971. Interstitial fluid pressure. Physiol. Rev. 51: 527-563.

26. Ussing, H. H. 1966. Anomalous transport of electrolytes and sucrose through the isolated frog skin induced by hypertonicity of the outside bathing solution. Ann. N. Y. Acad. Sci. 137 : 543-555.

27. Ussing, H. H., and B. Johansen. 1969. Anomalous transport of sucrose and urea in toad skin. Nephron. 6: 317328.

28. Franz, T. J., and J. T. Van Bruggen. 1967. Hyperosmolarity and the net transport of nonelectrolytes in frog skin. J. Gen. Physiol. 50: 933-949.

29. Feisal, K. A., J. Soni, and A. B. Dubois. 1962. Pulmonary arterial circulation time, pulmonary arterial volume and the ratio of gas to tissue volume in the lungs of dogs. J. Clin. Invest. $41: 390-400$. 
30. Read, R. C., J. A. Johnson, J. A. Vick, and M. W. Meyer. 1960. Vascular effects of hypertonic solutions. Circ. Res. 8: 538-547.

31. Rand, P. W., and E. Lacombe. 1965. Effects of angiocardiographic injections on blood viscosity. Radiology. 84: 1022-1032.

32. Jacobs, M. H. 1958. Measurement of cell permeability with particular reference to the erythrocyte. Mod. Trends Physiol. Biochem. 6: 149-171.

33. Katchalsky, A., and P. F. Curran. 1965. Nonequilibrium Thermodynamics in Biophysics. Harvard University Press, Cambridge, Mass. 113-132.

34. Patlak, C. S., and S. I. Rappoport. 1971. Theoretical analysis of net tracer flux due to volume circulation in a membrane with pores of different sizes. J. Gen. Physiol. 57 : 113-124.

35. Lifson, N. 1970. Revised equations for the osmotic transient method. In Capillary Permeability. C. Crone and N. A. Lassen, editors. Academic Press, Inc., New York. 302-305.

36. Shirley, H. H., Jr., C. G. Wolfram, K. Wasserman, and H. S. Mayerson. 1957. Capillary permeability to macromolecules: stretched pore phenomenon. Am. J. Physiol. 190: 189-193.

37. Pietra, G. G., J. P. Szidon, M. M. Leventhal, and A. P. Fishman. 1969. Hemoglobin as a tracer in hemodynamic pulmonary edema. Science. (Wash. D. C.). 166: 1643-1646. 